\title{
aniki
}

Revista Portuguesa da Imagem em Movimento

Portuguese Journal of the Moving Image

Tempo, Trânsito, Subjetividade em En Construcción (José Luis Guerín, 2000) e El Cielo Gira (Mercedes Álvarez, 2004) Rafael Tassi Teixeira ${ }^{1}$

\section{En Construcción}

En Construcción (José Luis Guerín, 2000) é um filme feito de uma multiplicação de situações: imagens-metamorfose (obtidas a partir de planos encadeados em diferentes profundidades de campo), tempo que ressoa na diegese, impondo sua devoração, imagensmemória (captadas em conjunções com o narrado, enfatizando a transformação arquitetônica), que se tornam errâncias dentro e fora do filme. Ou seja, é um filme feito de situações que tratam do habitar da sensibilidade fílmica ao tentar produzir proximidade, ao procurar detalhamentos.

Feito sobre um momento específico da Espanha da virada do milênio, sob o mito do boom econômico e da expansão imobiliária, o filme de Guerín estrutura-se a partir do pouso e da espera, das relações entre os habitantes do bairro barcelonês do Raval, crisol de múltiplas subjetividades provenientes de várias realidades migratórias, espaço que hospeda polissemias multiculturais, habitantes jovens e anciãos, pedreiros e prostitutas, crianças e rostos anônimos.

O filme espelha a própria condição da memória e os lugares do pertencimento histórico ao pensar as transformações urbanísticas da Espanha 'econômica' dos 2000, filtrando para dentro do jogo cinematográfico os relatos dos trabalhadores da construção civil e os muitos migrantes, certamente em uma metáfora da convivência possível e realizável: dividindo o plano fílmico nas falas do migrante marroquino e seu companheiro espanhol e instruindo a diegese com os processos transformadores (escavação no bairro que encontra restos da época romana, comensalidade entre interiores velhos e edificações ancestrais, paisagens permeadas por escombros, naturezas, transformações).

En Construcción será fundamental na história recente dos documentários espanhóis, pois trará, centralmente, o tema dos jogos de realidades e das tensões entre o instante narrativo, as cadeias de

1 Universidade Tuiuti do Paraná, Programa de Mestrado e Doutorado em Comunicação e Linguagens, 80035000, Curitiba (PPGCOM \UTP), Brasil; Universidade Estadual do Paraná (Unespar), Brasil. 
significado perdidas com o passo abrupto do tempo, a exploração esterilizante do estésico, do ético, do político na Barcelona da globalização emergente dos 1990-2000. Capturará esse trânsito estranho entre a história da transformação e a própria sobrevivência daquilo que se transforma, o elo da imagem com a arqueologia muda de uma realidade partícipe e também mais distante, como se o bairro intercultural do Raval barcelonês refletisse seu amplo espaço coabitado por crianças, anciões, imigrantes, trabalhadores, prostitutas, aposentados, abandonados, todos eles sujeitos e objetos de um lugar em constante reorganização das suas próprias fronteiras ${ }^{2}$.

Desse modo, no solilóquio de um mundo de profundidades do comum, relacionam-se materiais do estranhamento: o velho e o novo, a ruína e o escombro, o resquício e a reminiscência (Arfuch 2013). As primeiras imagens da escavação e os restos dos esqueletos dos habitantes do passado, lugar da incidência direta da memória que se movimenta, irrompem no quadro fílmico - a câmera que escolhe observar os rostos anônimos dos muitos habitantes do lugar, curiosos com os fragmentos extraídos debaixo da terra, memórias visuais e epifanias da transformação, ao mesmo tempo que revela e que esconde (um vazio cheio de presenças, uma plenitude carregada de silêncios).

O filme é construído sobre muitas derivas - trânsito entre velho e novo, figuração e metamorfose, decadência e sensibilidade, silêncio e voz, observação e narrativa - que demarca constantes situações da imagem e seu valor narrativo. São presenças e ausências que espelham um documentário com força subjetiva e também observacional, combinatório de ficção e realidade, de ênfase na indeterminação e na historicidade da alegoria: a forma fílmica, no filme de Guerín, tenta capturar as mudanças fisionômicas de um lugar caracterizado pelos arcaicos efeitos da acumulação, pela invasão do novo, pelo impulso sobre um tempo que eclode e um vazio que o faz proliferar. Sucessivos planos, ao longo da diegese, focalizam os edifícios do Raval, que sofrem constantes intervenções. A abertura do filme, por exemplo, trabalha com a insistência dos olhares dos transeuntes sobre restos arqueológicos encontrados no processo de escavação do lugar. As falas do pedreiro marroquino e do mestre-de-obras espanhol, da mesma forma, processam, ao longo de várias sequências, a combinação da construção das paredes de um novo edifício e a imagem de uma igreja antiga no fundo do plano. Nesse mesmo movimento da intencionalidade de registrar as intervenções arquitetônicas, aos 72 minutos da diegese, o filme estabelece um paralelo interessante entre o velho e o novo: a figura

\footnotetext{
${ }^{2}$ A identidade testemunhal da "insistência sintomática, a marca peremptória de um passado aberto como uma ferida" (Arfuch 2013, 13) avança metamorfose adentro, impondo suas mudanças - em geral sucessivamente duras, desmedidas, abruptas - diante de sujeitos distantes da narração.
} 
da menina, no edifício novo, que insiste em encontrar a mirada de um velho morador, do outro lado da rua, em uma construção decadente.

En Construcción, realizado em 2000 com vários colaboradores e estudantes do projeto do Master de Documental de Creacíon criado em 1998 na Universidad Pompeu Fabra (Barcelona) -, observa e narra as tensões entre a condição da perda \transformação do lugar de referência e a experiência limite da comunicação diante do fluxo da realidade - como se a ruína abalasse a representação, invertendo os processos de habitar e do pouso da história ${ }^{3}$. As ruínas, debilitadas pela intensidade da escavação, dividem o lugar com os novos moradores - o olhar obsedante e ausente dos últimos futuros inquilinos sobre novas janelas anti-ruído que abafarão a sonoridade (seus vasos comunicantes, suas teias gregárias), dimensionando outra vez o ausente e o visível, impedindo, interrompendo, emulando o desaparecimento e encarcerando uma e outra vez a possibilidade de contato.

No filme de Guerín, a paisagem aprenderá da encenação do encontro - pequeno acenar de mãos entre criança e ancião nos minutos finais. Refletirá uma miríade de situações de convivência em um bairro sob o jugo da exploração imobiliária, sob o peso (vazio) do tempo, as fontes debaixo da terra, repertórios do exílio em um lugar marcado, cada vez mais, pela exigência da transformação. Transformará, nesse processo, que será, portanto, a condição de um deslocamento fundante e fundamental: o novo no bairro em que a ausência parece ser destacada, desenvolvendo o movimento de mudanças, apresentando suas resistências comuns junto aos seus habitantes (as falas espiritualizadas entre o pedreiro marroquino e o cético mestre-de-obras espanhol).

Sobretudo, o tema do tempo, marcadamente subjetivo, inevitavelmente físico, adjacente, humano, irá potenciar a possibilidade dialógica da construção da memória - da vocação para seu rompimento, para sua insistência, para seu entrelaçamento. No filme de Guerín, a memória é uma prática (Català 2012) habitada por seu silêncio, devastada por sua transformação, uma substância (Jeudy 1990), contornada por seus ciclos, vertida sobre suas figurações, e também um conjunto (Rancière 2010) reconstruído por arranjos. Mostra-se uma produção sensível da alteridade - passado e presente habitando espectros divididos pela metamorfose permeada de signos relativamente fixos, de historicidades do

\footnotetext{
${ }^{3}$ Como escreve Català (2012, 209): "Las ruinas trabajan silenciosamente en las representaciones. Son el tiempo cristalizado en ellas, el pasado que su eterno presente pretende olvidar".
} 
comum, de temporalizações sentidas como sobrevivência e também como acontecimento ${ }^{4}$.

No filme de Guerín, vê-se a incidência de planos que trabalham os objetos do tempo: relógios, partes de antigos muros grafitados, pedras removidas, partes de ossos e esqueletos como vestígios de um passado a céu aberto. A diegese procura insistir sobre esse jogo estrutural entre o que é visto e o que pode ser observado. Várias sequências conservam, na profundidade de campo, a imagem de novos e velhos muros, com grandes gruas dividindo espaço com a paisagem arquitetonicamente alterada. A memória do bairro do Raval barcelonês surge nas falas dos habitantes mais velhos, mas também existe nas trocas de impressões dos trabalhadores imigrantes. Por exemplo, a observação cuidadosa, aos 40 minutos do fluxo fílmico, entre o pedreiro marroquino e seu compatriota novato: perspectivas que descrevem a substituição do lugar pela introdução das novas casas, enquanto a câmera cuidadosamente muda de lugar para, dois minutos mais tarde, ser possível enxergar a figura de uma moradora colocando roupas no varal, em um plano que é dividido em três profundidades (personagem estendendo roupas, uma grua em uma segunda profundidade, uma antiga igreja na paisagem mais funda).

De modo semelhante, o personagem do ancião, colecionista dos restos das construções, por exemplo, guarda objetos que vai encontrando pelo caminho e tenta vender, com uma fala sobre as coisas e seus gastos: um relógio antigo, uma máscara de mergulho, um isqueiro de metal. A conversa com o amigo em um bar, aos 102 minutos da diegese, prima pela evocação do que resiste a ser perdido no tempo. A sequência termina com o colecionador do lado de fora do bar, na rua de chão coberto de pó e escombros as caixas que utiliza para guardar os objetos.

Nesse sentido, prolifera uma vocação potente de muitos documentários da virada do milênio, estabelecidos diante do limite de sua condição de experimentação: ensaiam-se como inacabamento, preparam-se como escritas de interiores, intimidades de lugares de ausência e subjetivações, mas também de certo conjunto de redes de sentimentos (as formas autobiográficas, a observação mutante, o pensamento fílmico) que são inevitavelmente partícipes de uma teoria da transformação. Marcam, portanto, distâncias significativas com muitos documentários do passado (Gauthier 2011), fidedignamente presos à necessidade de ocultar os próprios mitos e transformações, de silenciar o peso da presença, de relativizar a intensidade da representação, de instruir o gesto estático como lugar

\footnotetext{
${ }^{4} \mathrm{O}$ acontecimento (Sahlins 2008) permeia o fluxo fílmico que tem a ver com suas longas e cíclicas durações: as dimensões entre o aparente e o entrelaçamento com o passado, os vestígios porosos do tempo em reminiscência (os restos físicos do passado, as dobras do presente), estabelecem vasos comunicantes, laços do tempo sobrevivido, em constante atualização.
} 
de eliminação (a tendência descritiva, o posicionamento fora do expressivo, o conhecimento dentro do recuo).

Ou seja, En Construcción ajuda a conceder maior amplitude às discussões sobre a força das formas subjetivas, destacadas na miseen-scène estruturada a partir de planos longos e sempre muito próximos dos sujeitos no filme, da imaginação fílmica (e, em paralelo, de qualquer situação cinematográfica). Valora a expressão subjetiva porque a imagem será sempre um modelo de relação, uma disposição para a transformação de uma visualidade (Català 2009) que pertence ao que pode ser partilhado nas relações entre o ato fílmico e as representações ${ }^{5}$.

O filme de Guerín circunda, sobretudo, um pensamento que delimita a visão do tempo como inevitavelmente cheio de máscaras, da circulação das distâncias, dos difíceis e infindáveis exercícios para definir uma memória presa às circunstâncias da paisagem e aquilo que ela reflete como "vazio circundante" (Català 2012). En Construcción, de modo constante, posicionar-se-á na articulação entre o inerte e o fluídico, o imaginário e o desaparecimento, a realidade e sua remodelação, o observacional e o criativo ${ }^{6}$.

Filtro paradigmático de um movimento que estabelecerá toda uma linha de força da reorganização do modelo realista, o filme de Guerín será um momento cinematográfico importante na história recente dos documentários na Espanha. Aqui, a ideia de realismo que paradoxalmente era lançada, diversas vezes, nos documentários do passado, faz proliferar diversidades de formas fílmicas que são registros de sensibilização, reflexões sobre o íntimo, o familiar e o estrangeiro, pontos de fuga e processos de atravessamentos do imaginário. O filme será uma espécie de espelho que faz sobreviver, ou faz viver de muitas novas formas, todos os intervalos, desequilíbrios, trânsitos, mutações da experiência representacional e das formas da imbricação - o interior, o estésico, o político, o ético ${ }^{7}$.

\footnotetext{
5 Mesmo os arquivos, quando irrompem as distâncias anteriormente 'testemunhais' das relações com o passado e a imposição fria de uma evocação, tornam-se, em múltiplos documentários contemporâneos, diversas linhas de recomposição das distâncias da evocação, da "imagem-emoção" (Català 2012), concebidas para serem rastro, vestígio, ritual, signos daquilo que era o esquecimento e passa a fecundar limites entre o familiar, o inconstante e o metaforizado; de certo modo, os documentários subjetivos reatualizam o efeito fraseal colocado sabiamente por Nietzsche: "Todo lo que es profundo ama la máscara" (1998, 32 ).

${ }^{6}$ En Construcción estará nos antípodas dos documentários de construção fílmica que tratam o tema do silêncio e da transformação da paisagem (como também Fuenteálamo, la carícia del tempo, Pablo García, 2001, El Cielo Gira, Mercedes Álvarez, 2004 e La Leyenda del Tiempo, Isaki Lacuesta, 2007), destacando-se, entre outros, o tema da fertilização da memória, da representação e dos deslocamentos, do arquitetônico e as metamorfoses; segundo Penafria (2011, 251), o filme de Guerín caracteriza-se por "substituir 'colocar em cena' por 'colocar em situação””. ${ }^{7}$ Como escreve Català $(2012,246)$ : “... la realidad está rodeada por el silencio de la ficción, de lo imaginario, mientras que la ficción lo está por el silencio del real.”
} 
Em En Construcción, os espaços são dissecados como ressonância do habitável, figurando a presença e seu simbolismo dizível. O fluxo fílmico passa a ser conjugado de diversas maneiras com a história da transformação, como se a imagem estivesse sempre em uma posição narrativa, ao mesmo tempo de escuta e de imaginação. No documentário de Guerín, a imagem será, portanto, uma imagem-profanação - ritualizada, muitas vezes, para dissuadir o acesso supostamente linear à captura dos corpos e seus entrelaçamentos com a paisagem. Será possibilidade e emancipação: duas forças de um cinema dedicado à escrita de uma pessoalidade aberta ao encontro, a todo movimento que há na disposição de ouvir (falas do pedreiro marroquino, interposições entre os observadores dos restos romanos, acessibilidades gestuais entre a menina nova inquilina e o velho morador do bairro). O tema do tempo e da memória carrega-se para dentro do habitar cinematográfico, capaz de realizar a expressão subjetiva amparando-se entre as profundas presenças das figuras da tela e sua marginalidade social, seu desejo de sobrevivência, suas dimensões errantes.

O cinema documentário de En Construcción, nesse aspecto, torna-se uma "modalidade de ficção" (Rancière 2010), que aprende com as diferentes maneiras de produzir transformações. O filme em si é marcante na história dos documentários espanhóis porque acessa a pessoalidade sem invadir sua metaforização, seu constante movimento de consciência do tempo sem o desencantamento que o estabiliza, sem a nostalgia que o torna ultrapassado. Isso é visível, por exemplo, na cena em que várias pessoas olham para dentro da escavação, aos 20 minutos da diegese, momento em que o fluxo fílmico avança, trazendo para dentro da mise-en-scéne sucessivos grupos de pessoas de diferentes idades, ouvidas na distância do quadro, enquanto a paisagem narrada mantém-se em segredo. Ou aos 45 minutos, noutra sequência em que a câmera observa os movimentos dos corpos dos transeuntes e a paisagem mutante, enquanto velho e novo se entrelaçam em imagens do bairro, nos pátios adjacentes, nos vidros das lojas.

Nesse aspecto, a imagem - temtativa, absoluta, centesimal, persistente - simplesmente não serve. O filme avança a partir das suas desintegrações, dos seus limites transcendidos, das suas marcas transpassadas, dos seus diálogos assistidos por seus silêncios urgentes, necessários ${ }^{8}$.

Marca característica será, para retomar o nosso exemplo, a visão das ruínas no começo da diegese. Os expectantes transeuntes do início do plano darão lugar aos novos inquilinos. Mas serão, eles mesmos, corpos atemporais que parecem, apesar das gruas, apesar do novo, resistir silenciosamente. Debaixo das linhas das agendas

\footnotetext{
${ }^{8}$ A espécie de fecundidade do habitável concede a possibilidade de observar na mise-en-scène derivas entre o visto e o filmado.
} 
programáticas, debaixo dos fluxos imobiliários, os habitantes da imagem resistirão sendo narrativos; o princípio de "em construção" é a escuta e o deslocamento, sua intensidade é a presença e a possibilidade aberta da imagem, da permeabilidade da palavra, da fluidez da representação.

En Construcción aprofunda ainda mais a questão do fracasso da metáfora fílmico-realista: para dentro e para fora do que sobra da imagem, o filme tornará ainda mais porosas as fronteiras entre o documentário e a ação narrativa. A imagem como uma criação do tempo, se ajusta com um intervalo diante de uma duplicidade: não é nem a contínua associação, não pode ser apenas matéria. O documentário de Guerín busca, portanto, essas pequenas costuras da intranquilidade, do campo de forças e sensibilidades que redirecionam o olhar, que convocam sua insuficiência, que congelam seu ordenamento, que alimentam seu imbricar'?

Com a capacidade de mascarar e ao mesmo tempo de expor, exibir, exigir uma ontologia fundamental, En Construcción, fecundará ainda mais o paradigma do cinema-documentário com a força da criação ambivalente: oscilações entre os limites da narrativa e o peso (físico) do acontecimento histórico diretamente sobre o fluxo diegético, intermitências dos limites da imagem e da incapacidade em reconhecer um único estado de limitação, sutilezas da metáfora entre os lugares que são profanados e os edifícios que são erguidos. Tornando acessível o que diretamente não se pode ver, fazendo presente e em constante oscilação aquilo que está diante dos olhos mas que tem a capacidade de negar-se como um espelho -, o filme de Guerín incidirá sobre os processos dos documentários mais declaradamente abertos à inconsistência do real, à transformação de seus simulacros, às várias maneiras de avançarem sobre as terminologias territorialistas, sentidamente falsas, vácuas, impossíveis de remeterem a transparências e as opacidades das imagens.

Alguns documentários espanhóis realizados posteriormente a En Construcción ${ }^{10}$ serão, multiplicadas vezes, influenciados pela produção de uma singularidade discursiva. Sobretudo, o tema coral da intranquilidade do objeto do olhar, a forma pensante da imagem e a força de demanda daquele que pensa a(s) relação(ões) da imagem com as superfícies ao redor (as marcas dos discursos, o espectador, os contextos de recepção, etc.), etc. Sob diversas linguagens -

\footnotetext{
9 A "pensatividade da imagem" ou a "pensatividade do sujeito da imagem" (Alloa 2015, 09).

${ }^{10}$ Por exemplo, La Leyenda del Tiempo (Isaki Lacuesta, 2005); Paradiso (Omar A. Razzak, 2013) e Árboles (Colectivo Los Hijos, 2013).
} 
sinestésica, quinestésica, histórica, alegórica, cinematográfica -, produzirão, portanto, o adiamento da imagem (Danto 2010) ${ }^{11}$.

O filme de Guerín é, assim, um sucessivo encarceramento. Mas um encarceramento temporário, vestido de metáforas (real, realidade, realismo) que jamais poderão ser abandonadas de seus quiasmas e perfurações (derramamentos, alegorias, representações, metamorfoses), das suas buscas nômades, insubstituíveis, por ser um processo de abertura a partir das consequências icônicas e das irrupções representacionais, mímesis e mèthexis (Nancy 2015), punctum e studium (Barthes 1984), ícone e transformação.

En Construcción rompe, de muitas formas, a questão da legibilidade da imagem (Didi-Huberman 2003) e seu poder de presunção da revelação. Não se trata de desmitificar um mito - a realidade como inscrição independente da ênfase histórica -, mas de produzir a aceitação da metamorfose: dos ciclos partidos entre realidade e ficção, do silêncio antes, durante e depois do personagem. Sobretudo, a trajetória de singularização e anonimato que expõe a inutilidade da visualidade sem subjetivação, e a perpendicularidade entre a busca cinematográfica e a busca da condição inexata, eternamente sob suspeita, da situação fílmica.

Sem urgência em filmar, o filme apoia-se na dualidade da dialética da exposição: a matéria que está ao redor, o sentido que se deixa apenas em um novo contato, as características que se conhecem somente quando da fusão (o acontecimento do limiar da imagem como acontecimento da infestação ${ }^{12}$ ).

Em En Construcción, vê-se, portanto, a oscilação - exibida em planos descontínuos feitos de vários fundos visuais -, a relação entre memória e imaginário. Da mesma forma se vê o relato do risco, enfrentamento, advertência do fotograma: quando, por exemplo, nos últimos vinte minutos, um grupo de familiares visita um apartamento recém-construído e vários enquadramentos captam, em relação e proximidade-distanciamento, os edifícios antigos ao fundo. Nesse aspecto, o cinema se revela meticuloso (a fala, a voz, a centralidade dos rostos, a imersão na textura da pele quase ao toque). Mas também mostrará a força do cinema 'primitivo' - a câmera objetivada em planos neutros, grande profundidade de campo, e liminaridade espaço-temporal.

Há, aqui, um lugar para a forma e a advertência do excesso: a antítese do sujeito que perde seu corpo, mas que elucida suas metamorfoses. O longo travelling que encerra o plano final aponta para isso: os dois jovens personagens transitam pelo bairro em

\footnotetext{
${ }^{11}$ Adiar como aderir ao que resiste a ser perdido, eliminado, extraído da 'janela' da representação, suspenso da geração de força daquilo que mantém a imagem e mantém sua relação.

12 "O cinema filma para além daquilo que sabem ou desejam os homens que dele se servem” (Comolli 2006, 32)
} 
transformação, enquanto a imagem captará a paisagem adjacente, silenciosa e decadente. O filme deixa de ser um código a decifrar e passa a imbricar-se com a perda da réplica: a imagem feita de carne e osso desde outra imagem, semelhante à imprecisão do dilema de manifestar uma ausência, de descrever uma densidade, de circular uma devastação. O uso do plano e contraplano em várias cenas ao longo da diegese (imagens dos esqueletos, antigas edificações, rostos dos transeuntes, etc.) expõe a característica do velho e do novo dividindo espaços.

Nesse sentido, En Construcción dissipa tanto o excesso das dimensões antropológicas do cinema como a funcionalidade comunicacional do visível, prematuramente convocados a causar potência, dissimuladamente realizados a vertebrar insuficiências. Instaura-se em uma ambiguidade marcada pelo campo do inapreensível, mas também da revelação, espécie de liminaridade das condensações e deslocamentos (Rancière 2015), das perspectivas e pontos de vista, da fugacidade e suas contínuas reverberações para dentro do quadro fílmico.

\section{El Cielo Gira}

Em El Cielo Gira (Mercedes Álvarez, 2004), o tempo absoluto da imagem se costura com o tempo relacional da memória. Também ele produzido como um documentário do projeto do Master de Documental de Creacíon da Universidad Pompeu Fabra, vertebra-se sobre a metáfora da desaparição ${ }^{13}$. O silêncio percorre toda a esfera da diegese, habitando a imagem da experiência, revelando seu fluxo físico, irrompendo na dimensão da insuficiência. Nesse sentido, o filme começa com um esvaziamento ${ }^{14}$.

Híbrido de ensaio situacional-biográfico - o relato narrativo da diretora sobre o povoado da infância -, o filme acompanha a vida cotidiana de uma pequena aldeia soriana perdida na geografia espanhola, emulando talvez a falta de referências e reverberando a intensidade mitológica de El Espíritu de la Colmena (Víctor Erice, $1973)^{15}$.

\footnotetext{
${ }^{13}$ De forma análoga a En Construcción, que se edifica sobre os processos de destruição (paisagem, ruína, arqueologia muda da história), e também de El Sol del Membrillo, que se inscreve sobre os processos de emancipação (da imagem, do olhar cineasta-olhar pintor, do sentido do anonimato em relação a biografia).

${ }^{14}$ Plano estacionado sobre a imagem de um quadro, rearranjo na diegese como elemento da paisagem (réplica da paisagem pictórica sobre a imagem do registro da história $\backslash$ memória); profundidade de campo, câmera estática, mobilidade ontológica das primeiras e furtivas figurações, sensação de estagnação no tempo, de longevidade do registro, do assemelhamento da inscrição (ouve-se, no povoado conhecido pelos registros dos dinossauros, a voz da anciã iniciar a produção da memória: "quando éramos jovens, eles ainda viviam...").

${ }^{15}$ A produção física de uma infância in illo tempore, o "começo do tempo" sobre uma geografia sem nome, as primeiras descobertas no mundo longe dos diálogos
} 
Figurando susceptibilidades e intervalos a partir de pequenos jogos de particularidades e estranhamentos, como, por exemplo, a cena em que dois sujeitos conversam sobre o passado enquanto escavam a terra, o filme densifica o comum, experienciando o regresso à infância, ao lugar da memória, ao primeiro ciclo da tentativa do entendimento do mundo em que se descobre um ser estranho. Nesse aspecto, El Cielo Gira compõe-se de paisagens imutáveis, da imanência de presenças que existiram (as marcas dos dinossauros, as pedras monolíticas encontradas em todo o caminho, os constantes assovios do vento que percorrem a diegese). E da história das primeiras figurações, dos corpos dos envelhecidos anciões recebendo sol na praça central, da aldeia com seus últimos 14 habitantes, depois de mais de mil anos de história de povoamento sucessivo.

Em processo paralelo, decorre a narrativa biográfica de Mercedes Álvarez sobre o lugar da infância, sobre a tentativa de recuperar a origem dos primeiros movimentos no mundo que se rememora e no mundo que se observa estacionado no tempo, preso às suas marcas físicas, dentro da mitologia anterior (universo das pedras e dos dinossauros/grandes répteis, ocupações silenciosas do vento). Com seus derradeiros registros humanos, revela-se um mundo que ciclicamente contorna ao próprio nascimento: depois dos últimos jovens que deixaram o lugar como migrantes, o povoado não recebe nascimentos de bebês há mais de vinte anos, os velhos esperam a morte.

Dois outros tempos narrativos percorrem a diegese: a fala de um casal ancião sobre a construção de um hotel de luxo em um antigo convento, enquanto utilizam o fogo como os antepassados, e o trabalho de um pintor que está cada vez mais cego, Pello Azketa, que insiste em pintar, compartindo com a narradora o relato sobre o esvaziamento do povoado, seus últimos fantasmas, suas vidas que desaparecem alma a alma. O tempo, nesse sentido, surge aqui como um recipiente que transporta o lugar da existência para a gênese do significado da memória. Impõe suas ramificações naquilo que ainda é humano: o olhar de dentro e de fora, a fala pausada dos habitantes longevos, o afastamento fantasmagórico sentido de uma visualidade ensaiada sobre um vazio repleto de paisagens que se perderam (Schama 1996).

Metáfora da desaparição e da paisagem diante de sua permanente transformação, a cegueira do pintor - que pergunta a todo momento sobre a cor - desnuda como o olhar se torna insuportável, tecido de sobrevivências, repleto de analogias que delineiam aquilo que é, muitas vezes, imperceptível para o tempo humano. As costuras silenciosas de El Cielo Gira revelam como uma

humanos, o primeiro e primitivo mundo habitado por animais, dissecado pelo vento e pelo silêncio em profundidade. 
civilização atinge seu ápice, perdura e irrompe em seu definhamento, diante da urgência de determinadas imagens para conceber o passo do tempo, para observar as janelas inscritas na relação de suas grandes (dólmens primitivos, pegadas ancestrais) e pequenas escalas (corpos humanos, cegueiras biológicas). Nesse sentido, no filme de Mercedes Álvarez, o tempo dobra-se sobre si mesmo, torna-se um componente estratigráfico, deixa-se atravessar pelo componente humano, mas não cessa de apagar, sobrepor, esconder sua subterrânea força silenciosa ${ }^{16}$.

O filme de Mercedes Álvarez reorganiza-se, então, a partir do arquivo e do fotográfico - densificações do vestígio e da história, alumbramentos sobre a emergência de um mundo em constante processo de oxidação e desaparecimento: o fluxo da imagem se torna o fluxo do esquecimento, porque também antecipa, prolonga, ocasionalmente avança sobre aquilo que está em agonia. Ou seja, a selvagem perfuração que o tempo diacrônico, composto de múltiplos habitares, de desconfianças sobre o entorno do registro, promove na inexorável construção de sistemas de relações - de interferências sobre a fabricação do registro, da sua capacidade estésica, de seu assemelhamento condicionável, particular, biográfico.

A presença da geografia ancestral em seus vestígios físicos, em suas paisagens imersivas, denota processos de revelação: tratores trabalhando a terra e expondo as cidades submergidas (traços do Império Romano na Nova Numancia), pedaços de materialidades, de ruínas e história da cultura (Huyssen 2014) ${ }^{17}$.

Os mundos são imediatamente possuidores de cada ciclo histórico, da presença da ocupação (humana e não humana), da sobrevivência das formas do esquecimento (Augé 2001) e da materialização da profundidade ${ }^{18}$. Nesse sentido, o trabalho diegético esconde suas espacialidades sensoriais que ampliam o relativismo dos movimentos da indagação - a voz narrativa e autobiográfica de Mercedes, a incapacidade em pensar o espaço sem

\footnotetext{
${ }^{16}$ A fotografia e o tempo, duráveis como os processos remanescentes, aos 42 minutos da diegese, quando um arquivo fotográfico surge e as fotos são envolvidas pelo relato, aquecidas pela voz humana, dissecadas como estilhaços do passado (Huyssen 2014).

${ }^{17}$ Tal como En Construcción, o documentário de Mercedes Ávarez escreve-se sobre o tempo desabitado, sobre as ruínas e seus intervalos, sobre os restos e as pequenas profundidades ainda à espera de serem reconhecidas - o arquivo solto, presente como ausência, designado apenas pelos vestígios, pelo abandono, pela devastação tempória.

${ }^{18}$ No filme de Mercedes Álvarez, a exploração dessas buscas que são, longe da restauração, o reconhecimento da biografia antes de ser história; a primeira infância, efeito de uma antropologia do imaginário, do prenúncio da interiorização, da longa metáfora dos olhos primitivos sobre a paisagem a ser compreendida como espera, como movimento imperceptível, como lugar de afeição (Cauquelin 2008).
} 
encontrar memória, sem entrar em comunicação, sem ativar o imaginário $^{19}$.

El Cielo Gira comparte com a terra a ser interpretada (cheia de ossos, repleta de silêncios $)^{20}$ o futuro de um envelhecimento: a instalação dos moinhos de energia eólica, a transformação da paisagem feita de árvores, pedras, campos e colinas isoladas, espécies de fixações pictográficas da amplidão de um tempo em que as formas não protestavam. Na voz diegética do casal de anciões - talvez os mais velhos do povoado -, surge o comentário, dentro do profundo escuro afastado pelo fogo alimentado lentamente, sobre o hotel de luxo (de referências e origens tão incertas como a localização desse pequeno mundo insular e programático): "Esto es un hotel para los ricos”.

Profundamente subjetivo e visual, eis um mundo, portanto, que corta o próprio tempo e que aponta para sua devastação, revelando uma intimidade (a voz narradora e biográfica de Mercedes) que tem a ver com o processo de descoberta do evento e do registro, da imagem e da imaginação, do cinema e seu território mnemotécnico ${ }^{21}$.

A câmera percorre as fantasmagóricas distâncias de dentro do antigo palácio e invade os silêncios medievais: a lâmina potente da máquina corta a pedra, enquanto os construtores comentam sobre a nova porta do hotel a ser criada; sobre a montanha de entulhos, restos fotográficos, peças arqueológicas e pedaços visuais do passado, consecutivamente aberto ao tempo presente, remanescente, mas incompleto, sob o peso da destruição e do destino turístico. Nesse processo, mistura-se a cacofonia de sons que entram na diegese e infestam a predominância da quietude, o trabalho anterior do vento, a proposição caudal da imagem, reverberando seus fragmentos, lacunas, fissuras, distâncias.

A paisagem, aqui, revela-se pela proporção com que reconstrói o tempo, organizando-se como um contrapeso ao

\footnotetext{
${ }^{19}$ Em El Cielo Gira, o plano metafórico inverte a condição do desterro produzido pela primeira emigração: o lugar é ato biográfico e ao mesmo tempo escuta, imaginário, intensidade, atravessamento, deambulação. Figurativamente, é como se a pequena aldeia desarrumasse o tempo longe dos ciclos humanos: a terra que precisa ser revirada, o céu que 'gira' e conduz ao processo de superposição de tempos históricos, diante da longevidade (as marcas não humanas, os registros do homem coletivo).

${ }^{20} \mathrm{O}$ diálogo dos dois anciões revirando as camadas de terra ajardinada onde encontram ossos; as sepulturas abertas; as marcas dos dinossauros na perpendicularidade austral do povoado; as incisões do tempo nas ruínas de um antigo palácio que servirá de hotel de luxo, despedidos seus últimos habitantes, emigrados todos os seus jovens.

${ }^{21} \mathrm{O}$ primeiro cinema, aquele que figura a ausência e não tem receio de observar a própria escavação, aquele que se instrui da artificialidade e da recomposição da mesma maneira com que, repleto de frescor, busca no mundo a amplidão perdida na alma: o cinema de Robert J. Flaherty, de Carl Dreyer, de Jean Renoir.
} 
processo de deterioração. A paisagem, nos enquadramentos demorados, funciona como um equilíbrio da impossibilidade de manter uma autonomia diante da relação com seus personagens.

A relação entre pintura e imagem, no âmbito final do filme, tem a ver com os limites dessa impossibilidade: a impossibilidade de ser, por muito tempo, uma mesma memória. O pintor que perde progressivamente a visão insiste em registrar a paisagem da infância: a aldeia se torna um lugar que é disposto menos pela representação figurada ou pela ilusão perspectivista (Villarmea e Rosário 2017) do que pela intensidade afetiva do processo de encontro - a paisagem, no filme, colide com o sentimento de imersão e referência, mas é desejo e é duração porque possibilita fluxo e adivinhamento, manifestação do imaginário, errância permissiva por formas da ausência, suporte e fonte ao mesmo tempo da duplicidade da tela, segundo o olhar, segundo a representatividade.

Por exemplo, a cena em que um dos habitantes do povoado contempla, no fundo visual, as aspas giratórias dos modernos moinhos de vento e em que, lentamente, a noturnidade invade o quadro. Da mesma forma, os muitos planos que reservam a sensação de um cômputo silencioso: a casa sem luz elétrica em que dois anciões contemplam o fogo, as imagens dos ambientes vazios de uma antiga edificação que dará lugar a um futuro hotel de luxo, o transporte das partes colossais dos novos moinhos, etc.

Sob a força da perspectiva, a paisagem se institui, mas também desvanece. A inutilidade da visão concede espaço à relevância do olhar - fingir, durar, fazer crer, insistir sobre o que não pode ser figurado - e, ainda assim, conduzir a experiência sobre a gênese subjetiva e pictográfica. O filme de Mercedes Álvarez reestabelece a importância da significação de uma espacialidade que só tem sentido quando do ponto de vista das relações entre tempo, imagem, memória, imaginário e biografia. Construída através de silêncios e, sobretudo, do ato de escuta (da disponibilidade para alcançar a transformação), da densidade com que o espaço subjetivo mescla-se com o espaço remanescente, o documentário presentifica a questão da presença (evoca a singularidade da lembrança, sempre em transformação).

A imagem do pintor que está ficando cego, na metragem final, avança sobre o domínio da evocação; retrata aquilo que contempla o lócus do imaginário, do processo de perda visual e, ao mesmo tempo, de intensificação das pequenas costuras das relações - ouvimos a voz indagadora do pintor pedindo pela descrição das cores no mundo, percebemos o sentido da imagem como um ambiente secreto, que pungentemente revela, mas também impede, obstrui, nega a emancipação biográfica: seguir criando imagens apesar da impossibilidade de substituir a imagem (perdida) a partir da indagação das cores; densificar as possibilidades de paisagem íntima 
com a paisagem pictorial; utilizar o ímpeto da memória pelo desejo de renovação, em uma nostalgia simetrizada pela força estésica ou pela força da representação ${ }^{22}$.

Nesse sentido, El Cielo Gira produz formas de perceber a umidificação histórica sob a volatividade do tempo, refletido na manifestação da busca pelos limites da ausência, pela intranquilidade ativa do imaginário, pela consciência da aproximação sempre $a$ posteriori, sempre dependente do sentido da distância e do antagonismo da presença (a forma com que a recuperação tem a ver sempre com sua perda, instantaneamente). Desse modo, a prática de um tempo perdido, mas que não se pretende simbolizado pela perda - irreversível, indisponível - surge no filme de Mercedes Álvarez como uma organização da ideia da paisagem, do fundo figurativo e potencialmente presente, constantemente em movimento, que trabalha sobre a longitude do enquadramento, com a geografia da(s) marca(s) da(s) presença(s), disponível porque foi matéria de enlace, porque investiga as relações físicas e imaginárias entre o ambiente e a força da representação ao fazer vibrar a locução memorialística.

A paisagem em El Cielo Gira é um personagem que coteja com as associações entre a distância do lugar e sua capacidade de derramar elementos (escombros, forças mudas e relacionais) de um passado que tem a ver com o entrecruzamento entre a temporalidade e a experiência do espaço ${ }^{23}$. O filme se visualiza pela incapacidade crescente de apenas visualizar. É um ensaio sobre a imensidão, diante das formações de novas experiências, do cuidado não-linear, do descuido palimpsesto. A paisagem (nunca estática) dissocia-se do escombro (sempre permanente). Ela produz a irrupção de um novo que, da mesma forma que o documentário de Guerín, avança sobre a matéria viva do passado, impondo sua matéria morta, distanciando a metamorfose, durando a casca.

El Cielo Gira termina com a imagem da memória destemporalizada pela pintura. Essa imagem é construída sobre a dialética da ausência, sobre a confirmação de um outro tempo, comum àquilo que se preenche como anti-historicidade, que se alinha com os diferentes níveis de interpretação e distanciamento da possibilidade de olhar: registro fantasmático, imaginário sobrevivente, alegoria relativizada. A cegueira progressiva do pintor do povoado reflete as impossibilidades de qualquer absolutismo do olhar \da mirada única, narração definitiva, fotografia ou lembrança visual territorializada.

\footnotetext{
${ }^{22}$ O filme como um composto de imersão e encenação do transitório, da indefinição do registro (mundo sempre aberto, predisposto à interpretação), da dessemelhança (Didi-Huberman 2003) entre a possibilidade de alterar aquilo que se vê diante de seu suporte arquivístico, referencial, fotográfico.

${ }^{23}$ Lugar, sedimento, localização mitológica, retorno ao começo dos tempos, suporte à instrução da mobilidade do imaginário, situação de permanente vontade de acolhimento afetivo.
} 
O tempo será, sempre, como em El Sol del Membrillo (Víctor Erice, 1992) um tempo relativo a uma infância de certa forma já reconhecidamente perdida, mas sobrevivente, porque segue refletindo a necessidade de uma busca. Este tempo (instantâneo, revelador, cinematográfico) é o tempo da liminaridade, da predicação do encontro (com o Eu partido, com a situação memorialística), da entrada e da saída do imaginário. É o tempo da liberdade para acreditar que a metáfora é apenas uma ponte para uma outra maleabilidade: a imagem inferencial habitada pela situação fantasmática e sua própria transformação (em agencia, em revisão de olhares). De outra forma, um imaginário arquetípico, densificado pela capacidade de ressoar a subjetividade no signo que se nutre da atividade fotográfica/visualizante. Por exemplo, as marcas das lascas na pedra que, na última meia hora, uma grande máquina corta lentamente. Da mesma forma, as longas tomas em que dois anciões conversam, nos caminhos vicinais da aldeia, sobre as pedras, os ciclos atmosféricos, o tempo diante dos caminhos cruzados. Nos primeiros minutos da diegese, as imagens das pequenas ruas vazias, a neve que cai devagar, os planos das casas fechadas.

No filme de Mercedes Álvarez, a memória, portanto, se ocupa da transformação das imagens pela genealogia dos significados que habitam um certo estado (paisagem) de organização do movimento do olhar, que é atingido pela informação infinita, pela aproximação sucessiva, pela admissão constante (o encontro com o outro encadeia novas narrativas sobre os lugares do passado, o espelhamento com a paisagem revela o novo labirinto da intimidade e a nova espectadorialidade transforma o filme). A força da subjetividade derrama-se para a metamorfose do olhar, ciclicamente condicionado a buscar e confrontar a experiência, a sobreviver na individuação constante através de um ensaio sobre si, sobre os outros, sobre os territórios mudos (infância, localidade de nascimento, bairro de criação) ${ }^{24}$.

A memória, portanto, se interpõe parcialmente à imagem (Agamben 2004) como um dever-devir de relação. As paisagens interna e externa colidem com a evocação biográfica, mas o filme não tem aura de intocabilidade: depende da insistência da atividade sincrônica da individuação e da forma não linear com que a história íntima espelha a história da humanidade. Sem a experiência permeada pelo afeto, o passado parece transformar-se em fotografia silenciosa.

\footnotetext{
${ }^{24}$ Mas, também, sobre a identidade e sua peregrinação (a centro de cultos erráticos e simbolizantes).
} 


\section{REFERÊNCIAS}

Agamben, Giorgio. 2004. Image et Mémoire. Paris: Desclée de Brouwer.

Alloa, Emmanuel. 2015. "Entre a Transparência e a Opacidade - O que a Imagem dá a pensar". In Pensar a Imagem, Emmanuel Alloa (org.). 07-18. Belo Horizonte: Autêntica.

Arfuch, Leonor. 2013. Memoria y Autobiografía. México: Fondo de Cultura Económica.

Augé, Marc. 2001. As Formas do Esquecimento. Almada: Íman Edições.

Barthes, Roland. 1984. A Câmara Clara: Nota sobre a Fotografia. Rio de Janeiro: Nova Fronteira.

Català, Josep Maria Domènech. 2012. El Murmullo de las Imágenes. Imaginación, Documental y Silencio. Barcelona: Shangrila.

-_-. 2010. La Imagen Interfaz: Representación Audiovisual y Conocimiento en la Era de la Complejidad. Bilbao: Universidad del País Vasco.

Cauquelin, Anne. 2008. A Invenção da Paisagem. Lisboa: Edições 70.

Danto, Arthur. 2010. A Transfiguração do Lugar Comum. São Paulo: Cosac Naify.

Didi-Huberman, Georges. 2003. A Semelhança Informe: Ou o Gaio Saber Visual Segundo Georges Bataille. Rio de Janeiro: Contraponto.

Gauthier, Guy. 2011. O Documentário: Um Outro Cinema. SP: Papirus.

Huyssen, Andreas. 2014. Culturas do Passado-Presente: Modernismos, Artes Visuais, Políticas da Memória. Rio de Janeiro: Contraponto.

Jeudy, Henri-Pierre. 1990. Memórias do Social. Rio de Janeiro: Forense Universitária.

Nancy, Jean-Luc. 2015. "Imagem, Mímesis \& Méthexis". In Pensar a Imagem, Emmanuel Alloa (org.). 55-73. Belo Horizonte: Autêntica.

Nietzsche, Friedrich. 1988. El Origen de la Tragedia. Madrid: Edaf.

Penafria, Manuela. 2001. "O Documentário Espanhol: Uma Análise de En Construcción”. Revista Doc On-line, n. ${ }^{\circ}$ 11, dezembro: 248-256.

Rancière, Jacques. 2015. "O Imagens querem realmente viver". In Pensar e Imagem, Emmanuel Alloa (org.). Pensar a Imagem. 1991-204. Belo Horizonte: Autêntica. 
——_. 2010. "A Ficção Documental: Marker e a Ficção da Memória”. Revista Arte e Ensaios PPGAV \EBA \UFRJ, n. ${ }^{\circ} 21$, dez.

Sahlins, Marshall. 2008. Metáforas Históricas e Realidades Míticas. Rio de Janeiro: Zahar.

Schama, Simon. 1996. Paisagem e Memória. São Paulo: Companhia das Letras.

Villarmea Álvarez, Iván e Rosário, Filipa. 2017. "A Paisagem no Cinema: Imagens para Pensar o Tempo através do espaço", Aniki: Revista Portuguesa da Imagem em Movimento. Vol.4, n. ${ }^{\circ}$ 1: 55-63.

\section{FILMOGRAFIA}

En Construcción [longa-metragem, Cor, 35mm]. Dir. José Luis Guerín. Espanha, 2001. 125 mins.

El Cielo Gira [longa-metragem, Cor, digital]. Dir. Mercedes Álvarez. Espanha, 2004. 115 mins.

Recebido em 28-5-2017. Aceite para publicação em 14-12-2018. 